\title{
Canning Characteristics of the Cobre Variety Sweetpotato
}

\author{
M. A. Gonzailez, J. Benero, and F. Sächez-Nieva ${ }^{1}$
}

INTRODUCTION

Two new varieties of sweetpotatoes have been developed by the Agricultural Experiment Station of the University of Puerto Rico, the Rico and the Cobre. Moscoso $(1)^{2}$ showed that both varieties yield better than the U.P.R.3 variety which has been used almost exclusively for canning. Sánchez, et al. (2) studied the canning characteristics of the Rico variety and compared its chemical composition with that of the U.P.R.3. The present paper deals with the evaluation of the canning characteristics of the Cobre variety. A comparison is made of its chemical properties and canning quality with these characteristics of the standard processing variety, the U.P.IR.3.

\section{EXPERIMENTAL PROCEDURES}

The two varieties of sweetpotatoes used in this study, the U.P.R.3 and Cobre, were obtained from the Gurabo Substation. They were harvested 135 days after planting, graded for size, and processed immediately. Only roots ranging in size from $1 / 2$ to 2 inches in diameter were used.

The sweetpotatoes were processed on a pilot-plant scale on a line with a capacity for processing 300 pounds per hour, as described by Sánchez, et al. (2), with the exception that the roots were preheated to inactivate the enzyme system to prevent discoloration, as suggested by Scott, et al. (3). The roots were washed in a soaking tank followed by a rinse in a rotary washer and then preheated in hot water. The roots were peeled in 10-percent lye at $210^{\circ} \mathrm{F}$. in a rotary lye-peeler. From the lye-peeler the roots were discharged into a rotary washer provided with high-pressure water sprays to remove lye and loosen the peel. Trimming immediately followed peeling and washing. The roots were kept under water before and after trimming to prevent discoloration.

The sweetpotatoes were packed in No. 2 plain tin cans with C-enameled ends, 14-ounce fill-in weight. Thirty-five-degree Brix syrup at $200^{\circ} \mathrm{F}$. was

${ }^{1}$ Assistant Chemical Engineer, Assistant Chemist, and Technical Director, respectively, Food Technology Laboratory, Agricultural Experiment Station, University of Puerto Rico, Río Piedras, P.R. Acknowledgment: The authors wish to express their gratitude to all members of the staff who assisted in the chemical analyses and organoleptic evaluations. Special recognition is given to (i. ColomCovas, Assistant Horticulturist of the Food Technology Laboratory, who was in charge of supplying the raw material used in this work.

2 Italic numbers in parentheses refer to Liternture Cited, pp. 111. 
added, and the cans were exhausted in a steam exhaust-box for 15 minutes to a center-can temperature of $165^{\circ} \mathrm{F}$. Immediately after closing, the cans were retorted for 45 minutes at $240^{\circ} \mathrm{F}$. and cooled to $100^{\circ} \mathrm{F}$. The cans were air-dried and stored at room temperature of $85^{\circ} \mathrm{F}$.

\section{ANALY'TICAL METHODS}

\section{ANALYSIS OF THE UNPROCESSED ROOTS}

The roots were selected at random and ground in a food-chopper. Individual samples were taken for moisture, starch, sugar, B carotene, and vitamin $\mathrm{C}$ determinations. This method of selection and preparation of samples has been shown to involve relatively small errors in sampling and in the chemical determinations (4).

The A.O.A.C. procedures were used (5) for moisture determinations. Duplicate samples of the ground pulp weighing about $10 \mathrm{gm}$. each were dried to constant weight in a vacuum oven at $70^{\circ} \mathrm{C}$. under a vacuum of 100 $\mathrm{mm}$. Loss in weight was calculated as percentage of moisture.

For determination of reducing and total sugars, $25-\mathrm{gm}$. samples of the ground pulp were transferred to a $250-\mathrm{ml}$. volumetric flask, $115 \mathrm{ml}$. of $54.3-$ percent alcohol were added, and the mixture was heated in a steam bath for 1 hour. After cooling, 95-percent alcohol was added to make to volume, and the mixture filtered. Two-hundred-milliliter aliquots were evaporated on a steam bath to 20 to $30 \mathrm{ml}$., transferred to $100-\mathrm{ml}$. volumetric flasks, saturated neutral lead acetate solution was added, and the mixture was allowed to stand 15 minutes. The solution was diluted to mark with water and filtered. The filtrate was deleaded with $\mathrm{Na}_{2} \mathrm{CO}_{3}$ and filtered. Reducing sugars were determined in the filtrate without inversion. Total sugars as invert were determined after inversion with hydrochloric acid. Sugars were determined by the Munson and Walker procedure (6).

$B$ carotene was determined in samples of the ground pulp by the Moore and Ely procedure, but using acetone as the extractant $(7,8)$.

Starch was determined by the method described by Carter and Neubert (9) for the determination of starch in apples. The standard spectrophotometric curve was prepared using a Spectronic 20 at $590 \mathrm{~m} \mu$.

For total-acidity determination a 10 -gm. sample of the ground pulp was made into a slurry with distilled water and titrated with $0.1 \mathrm{~N} \mathrm{NaOH}$ to $\mathrm{pH}$ 8.1 in a titrometer. Titrable acidity is expressed as percentage of anhydrous citric acid.

Color was measured in a Hunter Color and Color Difference Meter as follows: A whole root was cut lengthwise in halves, color was measured for the exposed flesh with the meter calibrated for $R_{d}, a$ and $b$, with a white standard. Readings from several roots of the same variety were averaged. 
Vitamin $\mathrm{C}$ was determined in samples of the ground pulp by the Ballentine iodate method (10).

\section{ORGANOLEPTIC TESTS}

The quality of the canned product was determined organoleptically by trained tasters from our own staff. Two methods were used to determine product quality and preference, the pair test and the hedonic scale. Samples of processed sweetpotatoes were presented to the tasters in an air-conditioned tasting booth under red light. The color of the samples were scored under daylight. In the pair tests, a sample of each variety was presented to the tasters and they were requested to taste both samples and to indicate their preference on the basis of tenderness, flavor, color, and appearance.

In the hedonic-scale method of measuring food preference, a 9-point scale expressed in terms of like and dislike was used to determine tasters preference for flavor and color of the processed sweetpotatoes. Samples were presented to the tasters under the conditions described above, and each sample was tasted and rated before the next was served.

\section{RESULTS}

\section{COMPOSITION OF THE UNPROCESSED ROOTS}

The results of the chemical analyses are given in table 1 . These values represents the average of three analyses for each variety, harvested 135 days after planting. The Cobre variety was found to be higher in moisture, reducing sugars, and vitamin C than the U.P.R.3; it was lower in $B$ carotene; it had a similar starch content.

Both varieties were found similar in total acidity and $\mathrm{pH}$. When the varieties were compared for color, the U.P.R.3 was found to have a deeper orange color. The difference in the intensity of orange color was indicated by higher $a$ and $b$ Hunter values, indicating a higher concentration of the red and yellows. This was to be expected from the higher B carotene content of the U.P.R.3 variety.

\section{PROCESSING CHARACTERISTICS}

Both varieties were preheated before peeling to inactivate the cathecol oxidase. The Cobre variety had to be preheated 30 minutes at $135^{\circ} \mathrm{F}$. for complete inactivation of the enzyme system while the U.P.R.3 had to be preheated for 30 minutes at $165^{\circ} \mathrm{F}$. to obtain a similar level of inactivation. This suggests a slower rate of heat penetration in the U.P.R.3 variety, which may be due to its lower moisture content.

Both varieties were peeled in 10 -percent lye at $210^{\circ} \mathrm{F}$. for 6 minutes. Both varieties were found casy to peel. After lye-peeling it was easy to remove all rags and excess lye from the roots by washing with water sprays in a rotary washer. The peeled roots were always found to be of bright 
orange color, free from discoloration. No difference in behavior during the peeling was observed, except that peeling losses were higher for the U.P.R.3, as seen from the data in table 2. Trimming losses were found higher also for the U.P.R.3 variety.

In these experiments a 56.66-percent recovery of roots for canning was obtained from the U.P.R.3 variety. Sánchez, el al. (2) reported 63.00-percent recovery of roots for canning of the U.P.R.3. This difference in yield may occur because the sweetpotatoes for the two experiments were planted

TABLE 1.-Chemical composition of raw roots of Cobrc and U.P.R.S sweelpotalo varieties expressed on wet basis

\begin{tabular}{|c|c|c|}
\hline Characteristic measured & Cobre & U.P.R.3 \\
\hline Moisture........ & 73.50 & 68.53 \\
\hline Total acidity as anhydrous citric. ........ percent & .134 & .1277 \\
\hline Reducing sugar $\ldots \ldots \ldots \ldots \ldots \ldots \ldots$ do. & 1.12 & .67 \\
\hline Total sugar as invert................ do. & 4.169 & 3.55 \\
\hline $\operatorname{Starch} \ldots \ldots \ldots \ldots \ldots \ldots \ldots \ldots \ldots$ do. & 22.69 & 21.11 \\
\hline Vitamin $C \ldots \ldots \ldots \ldots \ldots \ldots \ldots \ldots \ldots m g . / 100 \mathrm{gm}$. & 34.89 & 24.15 \\
\hline B carotene . . . . . . . . & 9.76 & 10.08 \\
\hline Specific gravity $\ldots \ldots \ldots \ldots \ldots \ldots \ldots \ldots \ldots \ldots \ldots \ldots$ & 1.029 & 1.041 \\
\hline \multicolumn{3}{|l|}{ Hunter color } \\
\hline$R_{t} \ldots \ldots \ldots$ & 44.38 & 41.64 \\
\hline$a \ldots \ldots$ & 24.80 & 28.78 \\
\hline$b \ldots$ & 28.45 & 30.27 \\
\hline
\end{tabular}

TABLE 2.-Percentage peeling and trimming losses, and recovery of roots for canning, for raw roots of Cobre and U.P.R.S swectpolato varietics (average figures from $S$ runs)

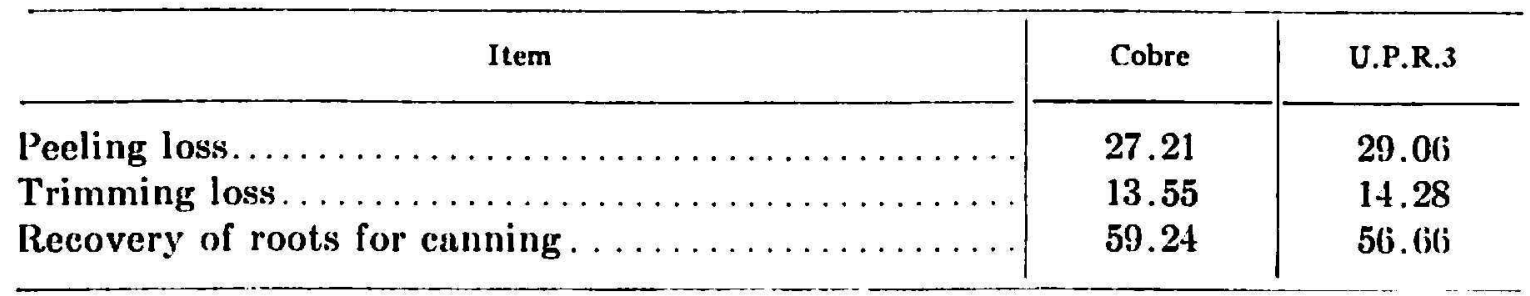

in different regions of the Island. The sweetpotatoes used by Sánchez, et al. (2) were planted at the Isabela Substation located in the northwest section of the Island, while the sweetpotatoes used in this experiment were planted at the Gurabo Substation, in the central castern section of the Island, where the soil and the elimatic conditions differ somewhat from those of the northwest.

SYRUPING, EXHAUSTING, AND COOKING

No difference could be observed between the two varieties during syruping, exhausting, and cooking. Neither of the two varieties was found to 
discolor appreciably during processing. Exhausting for 14 minutes to a can-center temperature of 160 to $165^{\circ} \mathrm{F}$. was found adequate to ensure a good vacuum in the can. All packs in the course of this work were processed using the time and temperature recommended by Sánchez, et al. (2).

\section{QUALITY OF THE CANNED PRODUCT}

As previously indicated, two methods were used to determine product quality and preference: The pair test and the hedonic scale. In using the pair test, a sample of each variety was presented to the tasters at the same time. They were required to indicate their preference for the different quality criteria.

The results of pair-test comparisons are given in table 3 , in which the percentage of tasters selecting a sample is indicated. Statistical analyses of

TABLE 3.-Results of pair-lest comparisons on canned Cobre and U.P.R.s sweetpolato varieties, showing percentage of lasters selecting samples for indicated quality criteria

\begin{tabular}{|c|c|c|c|c|c|c|}
\hline \multirow{2}{*}{ Quality criteria } & \multicolumn{6}{|c|}{ Percentage of tasters selecting sample- } \\
\hline & Cobre A & $\underset{A^{\prime}}{\text { U.P.R.3 }}$ & $\underset{\text { B }}{\text { Cobre }}$ & $\underset{\mathbf{B}^{\prime}}{\text { U.P. }} \cdot \mathbf{3}$ & Cobre C & U.P.R.3 $C^{\prime \prime}$ \\
\hline More attractive color. & 46.67 & 53.33 & 20 & 80 & $\mathbf{0}$ & $100^{*}$ \\
\hline Better flavor......... & 40.00 & 60.00 & 70 & 30 & 18.19 & $81.81 * *$ \\
\hline More tender............ & 48.33 & 51.67 & 75 & 25 & 37.39 & 62.61 \\
\hline
\end{tabular}

1 *Significant difference between samples at 5 -percent level and ** at 1-percent level.

the data show that no difference between tests $A-A^{\prime}$ and $B-B^{\prime}$. In test $C-C^{\prime}$, the U.P.R.3 was found to be more attractive in color, the result being significant at the 1-percent probability level. It was also found that the U.P.R.3 had better flavor, with the difference being significant at the 5-percent probability level.

Although it was possible to establish certain preferences between the varieties in the pairs studied, no conclusive results were obtained to indicate that one variety was better than the other.

When the samples were submitted to organoleptic evaluation no significant difference in preference was obtained using the 9-point hedonic scale for color and flavor. Both varieties were rated alike and highly accepted.

The difference between varieties was so small that it could hardly be detected in a pair or a hedonic test. It is to be expected that consumers would be unable to detect any difference in quality between varieties.

The results of these tests indicate that both varieties are similar from the standpoint of processing characteristies and flavor. The Cobre variety 
was found to be similar in many respects to the U.P.R.3 and, therefore, can be used successfully by canners.

\section{SUMMA RY}

The chemical composition of unprocessed roots, as well as the canning quality of the Cobre variety of sweetpotatoes was studied. Its behavior during processing, as well as the quality of the canned product, was compared with that of the U.P.R.3 variety. Unprocessed roots of the Cobre variety were found higher in moisture, reducing sugars, and vitamin $C$, but lower in $\mathrm{B}$ carotene. Recovery of roots for canning was 2.58 percent higher for the Cobre than for the U.P.R.3 variety. There was very little difference in the quality of the syrup-packed potatoes of the two varieties. Tasters displayed no preference for either variety.

\section{RESUMEN}

Se estudió la composición química de la batata de la variedad Cobre, así como su comportamiento durante su elaboración y la calidad del producto enlatado. Se comparó su comportamiento durante el enlatado y calidad del producto enlatado con los de batatas de la variedad U.P.R.3. La batata de la variedad Cobre contiene en su estado natural más humedad y un porcentaje de azúcares reductoras e invertidas totales más alto que la variedad U.P.R.3. Sin embargo, esta última es más rica en B caroteno.

Sa pudo establecer que el rendimiento de la batata elaborada fue un 2.58 por ciento mayor en la variedad Cobre. No se pudo establecer diferencia alguna en la calidad del producto envasado en sirop de estas dos variedades.

\section{LITERATURE CITED}

1. Moscoso, C., El Cultivo de la Batata en Puerto Rico, Bul. 126, Agr. Exp. Sta., Univ. P. R., 1955.

2. Sánchez-Nieva, F., Benero, J. R., and González, M. A., A Comparison of the canning quality of the Rico and the U.P.R. 3 sweetpotato, J. Agri. Univ. P. R., 42(4) 225-29, 1058.

3. Scott, I., Appleman, C. O., Wilson, M., The Discoloration of Sweetpotatoes During Preparation for Processing and the Oxidase in the Root, Univ, of Md., Bul. A33 (Tech.) 25, 1941.

4. - The Effect of Variety, Curing, Storage, and Time of Planting and Harvesting on the Carotene, Ascorbic Acid, and Moisture Content of Sweetpotatoes, Southern Co-op. Ser. Bul. 30, 11-2, 1953.

7. Moore, L. A., and Ely, R., Extraction of carotene from plant material; a rapid quantitative method, Ind. Eng. Chem. Anal. Ed. 13 600-1, 1941.

8. Official Methods of Analysis, Assn. Agr. Chem., Washington, D. C.

9. Carter, J. H., and Neubert, A. M., Rapid determination of starch in apples, Agr. \& Food Chem. 2 1070-2, 1954.

10. Ballentine, R., Determination of ascorbic acid in citrus juices, Ind. Eng. Chem. Anal. Ed. 13 89, 1941. 